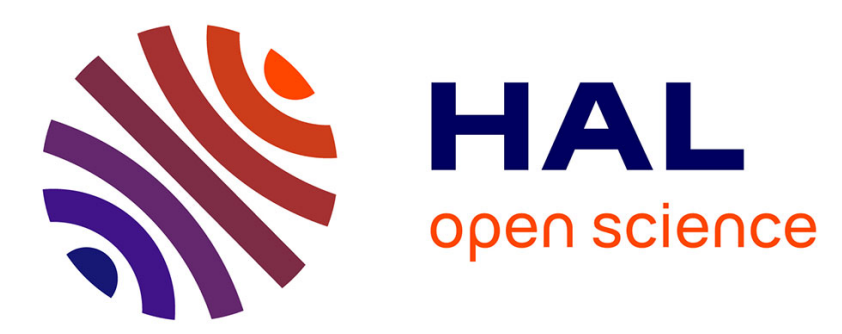

\title{
Structural and functional recovery of microbial biofilms after a decrease in copper exposure: Influence of the presence of pristine communities
}

A.S. Lambert, Soizic Morin, Joan Artigas, B. Volat, Marina Coquery, M. Neyra, S. Pesce

\section{To cite this version:}

A.S. Lambert, Soizic Morin, Joan Artigas, B. Volat, Marina Coquery, et al.. Structural and functional recovery of microbial biofilms after a decrease in copper exposure: Influence of the presence of pristine communities. Aquatic Toxicology, 2012, 109, pp.118-126. 10.1016/j.aquatox.2011.12.006 . hal-00674582

\section{HAL Id: hal-00674582 \\ https://hal.science/hal-00674582}

Submitted on 27 Feb 2012

HAL is a multi-disciplinary open access archive for the deposit and dissemination of scientific research documents, whether they are published or not. The documents may come from teaching and research institutions in France or abroad, or from public or private research centers.
L'archive ouverte pluridisciplinaire HAL, est destinée au dépôt et à la diffusion de documents scientifiques de niveau recherche, publiés ou non, émanant des établissements d'enseignement et de recherche français ou étrangers, des laboratoires publics ou privés. 


\title{
Aquatic Toxicology
}

Volume 109, March 2012, Pages 118-126

doi:10.1016/j.aquatox.2011.12.006

Received 16 September 2011; revised 5 December 2011; Accepted 6 December 2011.

Available online 14 December 2011.

\section{Structural and functional recovery of microbial biofilms after a decrease in copper exposure: Influence of the presence of pristine communities}

\author{
Anne-Sophie Lambert ${ }^{\mathrm{a}}$, Soizic Morin ${ }^{\mathrm{b}}$, Joan $_{\text {Artigas }}{ }^{\mathrm{a}}$, Bernadette Volat ${ }^{\mathrm{a}}$, Marina Coquery ${ }^{\mathrm{a}}$, \\ Marc Neyra ${ }^{a}$, Stéphane Pesce ${ }^{a}$ \\ a: Irstea, UR MALY, 3 bis quai Chauveau - CP 220, F-69336 Lyon, France \\ b: Irstea, UR REBX, 50 avenue de Verdun, F-33612 Cestas Cedex, France
}

Corresponding author:

Stéphane PESCE: Irstea, UR MALY, 3 bis quai Chauveau - CP 220, F-69336 Lyon, France; stephane.pesce@ irstea.fr ; phone +33472208795; fax +33478477875

Other e-mail addresses:

soizic.morin@irstea.fr

joan.artigas-alejo@irstea.fr

bernadette.volat@irstea.fr

marina.coquery@irstea.fr

marc.neyra@irstea.fr 


\begin{abstract}
The present study aimed at assessing the recovery of phototrophic and heterotrophic biofilm communities after a decrease in copper exposure. An original experiment was designed to evaluate the possible influence of non-exposed (i.e. pristine) communities (e.g. via immigration processes) in recovery dynamics. Laboratory channels were used to study the structural and functional changes in microbial communities after a 4-week $\mathrm{Cu}$ exposure period in the presence and absence of pristine biofilms. When pristine biofilms were present, phototrophic communities recovered within 6 weeks, both in terms of biomass, structure and photosynthetic activity. Recovery processes were also detected using the PICT approach. In contrast, in the absence of pristine communities, all of the $\mathrm{Cu}$-induced changes recorded in the phototrophic communities remained throughout the recovery period.

Regardless of the presence or absence of pristine biofilms, the decrease in $\mathrm{Cu}$ exposure did not abolish $\mathrm{Cu}$-induced changes in bacterial community structure, whereas functional recovery (based on beta-glucosidase activity) was complete in both recovery contexts.

These results revealed that microbial community response to a decrease in $\mathrm{Cu}$ exposure differs between phototrophic and heterotrophic communities. The presence of pristine communities greatly influences the structural and functional recovery of phototrophic communities, suggesting an important role of microbial immigration processes, but have far less influence on the recovery trajectory of heterotrophic communities.
\end{abstract}

\title{
Highlights
}

- We tested the influence of microbial immigration in biofilm recovery after a $\mathrm{Cu}$ exposure.

- Recovery dynamics differed between phototrophic and heterotrophic communities.

- Microbial immigration enhanced the recovery of phototrophic communities.

- Heterotrophic community recovery slightly depended on microbial immigration processes.

\section{Keywords:}

Bacteria; Diatoms; Immigration; Periphyton; Photosynthesis; PICT 


\section{Introduction}

The restoration of chemically contaminated aquatic ecosystems has become an important concern, especially through environmental policies such as the European Water Framework Directive (2000/60/EC), prompting growing interest in studying recovery trajectories and community resilience in aquatic environments ( [Depledge, 1999] , [Ivorra et al., 1999] , [Tolcach and Gómez, 2002] , [Dorigo et al., 2010a] and [Morin et al., 2010] ). In lotic ecosystems, periphytic biofilms assume key ecological functions such as primary production and nutrient cycling (Battin et al., 2003). These microbial assemblages are formed by phototrophic and heterotrophic communities, both of which are characterized by short generation times. This, together with the fact that they are the first to interact with dissolved substances, makes biofilms a candidate "early warning system" for detecting the effects of chemicals on aquatic systems (Sabater et al., 2007). Despite an increasing number of studies on the impact of toxicants on biofilm microbial communities, knowledge on their recovery dynamics following a decrease in exposure levels remains scarce (e.g. [Boivin et al., 2006] , [Dorigo et al., 2010a], [Dorigo et al., 2010b] , [Morin et al., 2010] and [Rotter et al., 2011] ). Aquatic environments are highly affected by metal pollution, with copper $(\mathrm{Cu})$ being one of the most commonly detected contaminants in surface waters ( [Bossuyt and Janssen, 2004] and [Serra and Guasch, 2009] ). Chronic exposure to $\mathrm{Cu}$ is known to result in structural and functional effects in autotrophic and heterotrophic biofilm microbial communities ( [Soldo and Behra, 2000] , [Boivin et al., 2006] and [Serra and Guasch, 2009] ). The resulting changes in microbial communities generally lead to an increase in community tolerance to $\mathrm{Cu}$, in line with the pollution-induced community tolerance (PICT) concept introduced by Blanck et al. (1988). The principle of PICT is that chronic contact with a toxicant can result in changes at the community level due to various toxicant-induced effects. These include individual acclimation (physiological or genetic adaptation) and loss of sensitive species. This increase in $\mathrm{Cu}$ tolerance following a chronic exposure was previously described in experimental studies considering phototrophic ( [Soldo and Behra, 2000] and [Tlili et al., 2010] ) and heterotrophic ( [Boivin et al., 2006] and [Tlili et al., 2010] ) activities as microbial endpoints. Several weeks after transferring biofilms from a $\mathrm{Cu}$-polluted downstream site to a reference upstream site exhibiting lower $\mathrm{Cu}$ concentrations, Dorigo et al. (2010a) observed a low decrease in algal and bacterial community tolerance to $\mathrm{Cu}$, suggesting a slow recovery curve for these communities. In situ translocation experiments applying the PICT concept to assess 
biofilm recovery were also recently performed for organic pesticides, confirming that PICT approaches can be a suitable tool for the study of microbial recovery processes following toxicant exposure ( [Dorigo et al., 2010b] and [Rotter et al., 2011] ).

In situ studies provide the most realistic assessment of field conditions, but translocation approaches have limitations hampering effective assessment of the recovery potential of microbial communities following a decrease in exposure to a contaminant or class of contaminants. These limitations mainly stem from the fact that the studied sites (before and after biofilm translocation) generally differ not only in terms of toxicant concentrations but also in terms of nutrient content or other environmental (e.g. light, water flow, etc.) properties that can strongly influence microbial dynamics. Moreover, recovery is an ecological process driven, at least partially, by immigration of new organisms (Morin et al., 2010). Immigration processes are probably facilitated in translocation studies, since the exposed biofilms are transplanted into river sections colonized by indigenous communities. Indeed, [Stevenson and Peterson, 1989] and [Stevenson and Peterson, 1991] have shown that immigration processes are a major driver of the colonization and recovery dynamics of diatom communities. Therefore, the observed recovery trajectories which result from changes in exposure conditions after the translocation are also assisted by such immigration processes. However, it remains virtually impossible to discriminate in translocation studies between the effects of regrowth of remaining viable cells when pollution pressure decreases vs. re-colonization by new immigrants.

Given this background, the main purpose of the present study was to test the ability of natural microbial biofilm communities to recover after copper exposure in laboratory channels. An original experimental approach was designed to assess the influence of the presence of pristine communities on recovery dynamics. Given the structural and functional complexity inherent to microbial biofilms, we hypothesized that recovery trajectories could vary between phototrophic and heterotrophic communities. Accordingly, a combination of methods was applied to assess microbial response following a decrease in $\mathrm{Cu}$ exposure in terms of biomass (dry weight, chlorophyll a content), structure (algal classes), diversity (diatom taxonomic analysis, bacterial genetic diversity) and phototrophic and heterotrophic functions. In addition, we used a PICT approach to detect variations in copper tolerance in phototrophic and heterotrophic communities. We expected recovery to be made faster by the presence of pristine communities via microbial immigration processes. 


\section{Materials and methods}

\subsection{Experimental setup}

The experiment was carried out in 4 indoor glass channels composed of three independent compartments $(1 \times \mathrm{w} \times \mathrm{d}=63 \mathrm{~cm} \times 11 \mathrm{~cm} \times 4 \mathrm{~cm})$ used as pseudo-triplicates (independent compartments supplied with the same water). Channels were used in recirculating mode throughout the study: $50 \mathrm{~L}$ of water was recirculated from a glass aquarium through centrifugal pumps at a rate of about $1.2 \mathrm{~L} / \mathrm{min}$ (Rena Flow 600). High-pressure sodium lamps were used to obtain a constant light intensity of 3500 lux under a $13 \mathrm{~h} / 11 \mathrm{~h}$ light/dark regime. The study was conducted for 11 weeks, from January 25th to April 13th 2011 under laboratory ambient temperature conditions (about $21^{\circ} \mathrm{C}$, Table 1). During the first week, all the channels were filled with river water, and a suspension of natural biofilms (collected on stones) sampled in January 2011 at the upstream site of the Morcille River (Beaujolais, Eastern France, see Montuelle et al. (2010) for details) to allow biofilm settlement on artificial substrates (microscopic glass slides) previously placed at the bottom of each channel. Concentration of dissolved $\mathrm{Cu}$ in the river water was less than $0.9 \mu \mathrm{g} \mathrm{L}-1$. Then, the channels were filled with drilled groundwater containing very low concentrations of $\mathrm{Cu}(<0.3 \mu \mathrm{g} \mathrm{L}-1)$ and adjusted to the sampling site conductivity (i.e., $600 \mu \mathrm{S} \mathrm{cm}-1$ ) and nutrient concentrations (i.e. about $4 \mathrm{mg} \mathrm{Si} \mathrm{L-1,} 5 \mathrm{mg} \mathrm{NO3} \mathrm{L-1,} \mathrm{and} 0.05 \mathrm{mg} \mathrm{PO}$ L-1). Two channels (called "Control") were used as control channels (without $\mathrm{Cu}$ addition) and two channels (called "Cu") were supplemented with $\mathrm{CuSO} 45 \mathrm{H} 2 \mathrm{O}$ to obtain a $\mathrm{Cu}$ concentration close to the highest concentrations recorded in the downstream section of the Morcille river (i.e. about 20 $\mu \mathrm{g} \mathrm{Cu} \mathrm{L-1,} \mathrm{Montuelle} \mathrm{et} \mathrm{al.,} \mathrm{2010).} \mathrm{During} \mathrm{this} \mathrm{period,} \mathrm{water} \mathrm{was} \mathrm{renewed} \mathrm{weekly} \mathrm{to}$ maintain a relatively constant exposure level and to avoid nutrient depletion. The 4-week exposure period was followed by a 6-week recovery period: two channels were respectively kept as "control" and "Cu" channels identical to those described above, while the two other channels (called "ExCu1" and "ExCu2", respectively) were not supplemented with $\mathrm{Cu}$ anymore. The "ExCu1" channel was designed to mimic a translocation experiment in order to test the influence of the presence of pristine communities on recovery dynamics. Accordingly, this channel was composed of half non-exposed biofilms (taken from "control" channels) and half previously exposed biofilms (taken from " $\mathrm{Cu}$ " channels). In channel ExCu1, biological assessments were only conducted on biofilms previously exposed in $\mathrm{Cu}$ channels. The last channel ("ExCu2") was only composed of previously exposed biofilms (taken from "Cu" 
channels) to assess their recovery potential following a decrease in copper exposure without the possibility of microbial immigration from unexposed communities. During this period, water was renewed every two weeks.

Table 1. Physico-chemical characteristics (mean values of biweekly samples \pm standard deviation (s.d.)) of water in the 4 channels before and $2 \mathrm{~h}$ after each water renewal during the recovery period (weeks $0,2,4$, and 6). DO, dissolved oxygen; TOC, total organic carbon; DOC, dissolved organic carbon.

\begin{tabular}{|c|c|c|c|c|c|c|c|c|c|c|}
\hline \multirow[b]{3}{*}{$\mathrm{pH}$} & \multirow{2}{*}{\multicolumn{2}{|c|}{$\begin{array}{c}\text { Initial conditions } \\
\text { (after water renewal) } \\
\text { All the channels } \\
(\mathrm{n}=36)\end{array}$}} & \multicolumn{8}{|c|}{$\begin{array}{c}\text { Conditions after } 2 \text { weeks } \\
\text { (before water renewal) }\end{array}$} \\
\hline & & & \multicolumn{2}{|c|}{$\begin{array}{c}\text { Control } \\
(n=9)\end{array}$} & \multicolumn{2}{|c|}{$\begin{array}{c}\text { ExCu1 } \\
(n=9)\end{array}$} & \multicolumn{2}{|c|}{$\begin{array}{c}\text { ExCu2 } \\
(n=9)\end{array}$} & \multicolumn{2}{|c|}{$\begin{array}{c}\mathbf{C u} \\
(\mathrm{n}=9)\end{array}$} \\
\hline & 7.9 & \pm 0.1 & 8.0 & \pm 0.2 & 8.1 & \pm 0.2 & 8.0 & \pm 0.2 & 8.0 & \pm 0.2 \\
\hline Conductivity $\left(\mu \mathrm{S} . \mathrm{cm}^{-1}\right)$ & 129.4 & \pm 16.3 & 121.6 & \pm 22.8 & 114.7 & \pm 19.3 & 116.4 & \pm 18.6 & 117.5 & \pm 20.1 \\
\hline $\mathrm{DO}\left(\mathrm{mg} \cdot \mathrm{L}^{-1}\right)$ & 8.6 & \pm 0.5 & 7.1 & \pm 2.0 & 7.3 & \pm 2.1 & 7.7 & \pm 2.5 & 7.0 & \pm 2.7 \\
\hline Temperature $\left({ }^{\circ} \mathrm{C}\right)$ & 20.8 & \pm 0.5 & 21.3 & \pm 1.1 & 22.0 & \pm 1.0 & 21.6 & \pm 1.1 & 21.4 & \pm 1.0 \\
\hline $\mathrm{TOC}\left(\mathrm{mg} \cdot \mathrm{L}^{-1}\right)$ & 1.94 & \pm 0.45 & 7.83 & \pm 2.92 & 9.57 & \pm 3.68 & 8.17 & \pm 2.65 & 8.15 & \pm 2.55 \\
\hline $\mathrm{DOC}\left(\mathrm{mg} \cdot \mathrm{L}^{-1}\right)$ & 1.06 & \pm 0.36 & 6.42 & \pm 1.05 & 7.52 & \pm 4.29 & 5.48 & \pm 3.88 & 3.87 & \pm 1.98 \\
\hline $\mathrm{NO}_{3}\left(\mathrm{mg} \cdot \mathrm{L}^{-1}\right)$ & 4.06 & \pm 0.48 & $<1$ & & $<1$ & & $<1$ & & $<1$ & \\
\hline $\mathrm{NO}_{2}\left(\mathrm{mg} \cdot \mathrm{L}^{-1}\right)$ & 0.04 & \pm 0.01 & 0.02 & \pm 0.01 & 0.02 & \pm 0.02 & 0.04 & \pm 0.02 & 0.05 & \pm 0.03 \\
\hline $\mathrm{NH}_{4}\left(\mathrm{mg} \cdot \mathrm{L}^{-1}\right)$ & $<0.01$ & & 0.01 & \pm 0.01 & 0.01 & \pm 0.01 & 0.02 & \pm 0.02 & 0.02 & \pm 0.01 \\
\hline $\mathrm{PO}_{4}\left(\mathrm{mg} \cdot \mathrm{L}^{-1}\right)$ & 0.04 & \pm 0.02 & 0.08 & \pm 0.05 & 0.10 & \pm 0.02 & 0.10 & \pm 0.03 & 0.07 & \pm 0.01 \\
\hline $\mathrm{SiO}_{2}\left(\mathrm{mg} \cdot \mathrm{L}^{-1}\right)$ & 4.22 & \pm 1.19 & 1.27 & \pm 1.25 & 5.03 & \pm 0.85 & 9.50 & \pm 0.56 & 10.30 & \pm 1.21 \\
\hline
\end{tabular}

\subsection{Water analysis}

Throughout the entire study, the main physico-chemical parameters and total dissolved $\mathrm{Cu}$ concentrations were measured before and $2 \mathrm{~h}$ after each water renewal ("exposure" and "recovery" periods).

Temperature, $\mathrm{pH}$, conductivity, dissolved oxygen, and the concentrations of total organic carbon (TOC), dissolved organic carbon (DOC) and the primary dissolved nutrients (NO3, $\mathrm{NO} 2, \mathrm{NH} 4, \mathrm{PO} 4$ and $\mathrm{SiO} 2$ ) were measured following French standard operating procedures. In order to measure total dissolved $\mathrm{Cu}$ concentrations, $30 \mathrm{~mL}$ of channel water was filtered (0.45 $\mu \mathrm{m}$ polyvinylidene difluoride (PVDF), Whatman) and acidified with $0.5 \%$ of nitric acid (Suprapur, Merck) before being stored at $4{ }^{\circ} \mathrm{C}$ until analysis. Filtered samples were analyzed using inductively coupled plasma-mass spectrometry (ICP-MS X Series II, Thermo Electron). Quality controls were routinely checked using a certified reference material (Environment Canada, TM 27-3, Lake Ontario natural water). 


\subsection{Analysis of copper in biofilms}

$\mathrm{Cu}$ concentrations in biofilms were analyzed before each water renewal during the "recovery" period (weeks 0, 2, 4 and 6) as previously described by Tlili et al. (2010). Briefly, biofilm was scraped from two glass substrates per replicate and suspended in $50 \mathrm{~mL}$ of Ultra-pure water (Milli-Q). This suspension was divided into two fractions of $20 \mathrm{~mL}$, which were treated or not with $320 \mu \mathrm{L}$ of EDTA $(0.25 \mathrm{M})$ to quantify internalized $\mathrm{Cu}$ and total in-biofilm $\mathrm{Cu}$, respectively. The biofilm suspensions were filtered $(0.45 \mu \mathrm{m}, \mathrm{PVDF}$, Millipore) and dried for $48 \mathrm{~h}$ at $50{ }^{\circ} \mathrm{C}$. Dried samples were digested with $3 \mathrm{~mL}$ of concentrated nitric acid (Suprapur, Merck), and Ultra-pure water (Milli-Q, Millipore) was added to dilute the acid concentrate. Finally, $\mathrm{Cu}$ analysis was performed as described above. Quality controls were routinely done using a certified reference material (IRMM, BCR 414, plankton).

\subsection{Biofilm characterization}

Phototrophic and heterotrophic communities were characterized every two weeks during the "recovery" period (weeks 0, 2, 4, and 6). Biofilms were carefully removed from slides using a razor blade, then suspended in mineral water (Volvic, France) before all analysis described below. Biofilm dry weight (DW) and ash-free dry mass (AFDM) were determined as described in Morin et al. (2010).

Phototrophic communities: Total chlorophyll a (chl a) and proportion of diatoms, chlorophyceae and cyanobacteria were determined by a multi-wavelength pulse amplitudemodulated (PAM) fluorometer on a Phyto-PAM system (H. Walz) as described in SchmittJansen and Altenburger (2008). Photosynthetic efficiency was also estimated with the PhytoPAM fluorometer using the saturation pulse method to determine PSII quantum yield (Schmitt-Jansen and Altenburger, 2008). Diatom sample preparation and taxonomic identification were performed following European standard NF EN 13946. About 400 frustules were counted per slide at 1000× magnification, and diatoms were identified to the lowest taxonomic level possible using standard references (Krammer and Lange-Bertalot, 1986-1991) and recent nomenclature updates. 
Heterotrophic communities: Bacterial community structure was analyzed using automated ribosomal intergenic spacer analysis (ARISA) following Tlili et al. (2011) with slight modifications. Briefly, biofilm DNA was extracted using the FAST DNA kit (QBIOgene) according to the manufacturer's instructions. The 16S-23S bacterial intergenic spacer region was amplified using the primers S-D-Bact-1522-b-S-20 (eubacterial rRNA small subunit, 50TGCGGCTGGATCCCCTCCTT-30) and L-DBact-132-a-A-18 (eubacterial rRNA large subunit, 50-CCGGGTTTCCCCATTCGG-30) (Ranjard et al., 2001) as described by Tlili et al. (2011). ARISA analyses were performed using an Agilent 2100 Bioanalyzer (Agilent Technology) following the manufacturer's instructions, and ARISA profiles were analyzed using GelCompar II software (Applied Math NV) to output a matrix based on the quantification of relative band intensities. The extracellular enzymes leucine-aminopeptidase (LAP) and $\beta$-glucosidase $(\beta$-Glu) were measured using the fluorescent-linked substrates aminomethylcoumarin (AMC) and methylumbelliferyl (MUF), respectively (Sigma-Aldrich), according to Romani et al. (2004). Each biofilm suspension $(0.7 \mathrm{~mL})$ was incubated with 2 $\mathrm{mL}$ of the specific artificial substrate for each enzyme, at the previously determined saturating concentration. After $1 \mathrm{~h} 15 \mathrm{~min}$ incubation in the dark in a shaker, glycine buffer (pH 10.4, $0.3 \mathrm{~mL}$ to each sample) was added to stop the enzyme reaction and reach maximum AMC and MUF fluorescence, which was measured on a Biotek synergy HT fluorometer at 360/460 nm excitation/emission.

\subsection{Short-term bioassays and tolerance assessment}

Phototrophic and heterotrophic biofilm community tolerances to $\mathrm{Cu}$ were assessed using chlorophyll fluorescence and extracellular enzymatic activities (LAP and $\beta$-Glu) as endpoints (Tlili et al., 2010). A semi-logarithmic series of $\mathrm{Cu}$ concentrations was freshly prepared in sterile filtered Milli-Q water to obtain $\mathrm{Cu}$ concentrations ranging from 0.127 to $1270 \mathrm{mg} \mathrm{L}-1$. For bioassays based on chlorophyll fluorescence (phototrophic communities), biofilm suspensions $(2.7 \mathrm{~mL})$ were exposed to increasing concentrations of $\mathrm{Cu}(0.3 \mathrm{~mL})$ for $2 \mathrm{~h} 30$ min in a climatic chamber (MLR-350 Versatile Environmental Test Chamber, Sanyo) at a constant $21{ }^{\circ} \mathrm{C}$ under artificial light (1400 lux). Samples were kept for $30 \mathrm{~min}$ in a dark chamber, and then chlorophyll fluorescence (F0) was determined on a Phyto-PAM fluorometer. For bioassays based on LAP and $\beta$-Glu extracellular enzymatic activities (heterotrophic communities), biofilm suspensions $(0.7 \mathrm{~mL})$ were exposed to increasing 
concentrations of $\mathrm{Cu}(0.3 \mathrm{~mL})$ for $4 \mathrm{~h}$ (in the dark, at $20^{\circ} \mathrm{C}$, under gentle shaking) before being incubated with the two specific artificial substrates and analyzed as described above.

For all of the bioassays and for each sample triplicate, we ran four blanks and three analytical replicates with each of the nine increasing concentrations of $\mathrm{Cu}$. PSII yield values observed for "analytical blanks" in PICT assessment with phototrophic communities (data not shown) were similar to those directly measured after sampling in the channels revealing that incubation in the climatic chamber had no effect on the physiological status of phototrophic communities. For each sample triplicate, EC50 value was calculated by performing a nonlinear regression on Hill's model using REGTOX software (version EV7.0.5., E. Vindimian, http://eric.vindimian.9online.fr/) integrating the optimal EC50 value (as determined by the model). EC50 values obtained for phototrophic (chl fluorescence) and heterotrophic (LAP and $\beta$-Glu activities) parameters were normalized to chl a contents (Soldo and Behra, 2000) and to AFDM, respectively.

\subsection{Data processing}

All between-treatment comparisons (biofilm characteristics and EC50 values) were performed using two-way ANOVA with repeated measures followed by a Tukey's post hoc test ( $\mathrm{p}<$ 0.05) using the Microsoft Excel add-in program xlstat-ada (version 2009.4.02, http://www.xlstat.com/). All data were log-transformed prior to ANOVA analyses to ensure normality of data and homogeneity of variances.

Structural data, including diatom taxonomic analysis and bacterial ARISA profiles, were compared by non-metric multidimensional scaling (NMDS) using the matrix obtained from relative abundance analysis. Comparison of diatom communities was done by considering only the species representing more than $1 \%$ relative abundance in at least one sample. NMDS was performed using the labdsv package (http://ecology.msu.montana.edu/labdsv/R/labdsv) for the R statistical environment (Ihaka and Gentleman, 1996).

\section{Results}

\subsection{Physico-chemical data}

Table 1 reports the mean values of the main physical and chemical variables measured in the four channels during the 6-week recovery period. Temperature, $\mathrm{pH}$, conductivity, and 
concentrations of dissolved oxygen, $\mathrm{NH} 4, \mathrm{NO} 2$ and PO4 remained relatively stable between each water renewal, whereas the concentrations of organic carbon (TOC and DOC) and NO3, statistically increased and decreased, respectively, in all channels $(\mathrm{p}<0.05)$. Statistical analysis revealed no significant differences between the four channels for these physicochemical parameters. The only statistical differences found between the channels at two weeks after each water renewal concerned silica (SiO2) concentrations, which were significantly lower in the control and $\mathrm{ExCu} 1$ channels than in the $\mathrm{Cu}$ and $\mathrm{ExCu} 2$ channels (p $<$ 0.05). Except for ExCu1, $\mathrm{SiO} 2$ concentrations measured before each water renewal statistically differed from initial conditions $(\mathrm{p}>0.05)$, revealing a notable uptake (Controls) or release (ExCu2 and $\mathrm{Cu}$ channels) of this compound.

\subsection{Copper concentrations}

In control channels, dissolved $\mathrm{Cu}$ concentrations remained under $3 \mu \mathrm{g} \mathrm{L}-1$ throughout the study (Fig. 1), while total $\mathrm{Cu}$ in biofilms decreased from about 44 to $25 \mu \mathrm{g} \mathrm{Cu}$ g-1 DW during the recovery period (Fig. 2A), with a high percentage of internalized $\mathrm{Cu}$ (75-88\%). In $\mathrm{Cu}$ channels, dissolved $\mathrm{Cu}$ concentrations ranged from 14 to $25 \mu \mathrm{g} \mathrm{L}-1$, and decreased notably between most water renewals (Fig. 2). During the recovery period, total $\mathrm{Cu}$ was 30- to 55-fold higher in exposed biofilms (1200-1450 $\mu \mathrm{g} \mathrm{Cu}$ g-1; Fig. 2D) than in control channels, while the proportion of intracellular content increased progressively from week $0(27 \%)$ to week $6(57 \%)$.

Fig 1.. Mean dissolved $\mathrm{Cu}$ concentrations ( $\mu \mathrm{g} \mathrm{L}-1)$ measured in each channel during the exposure and recovery periods. Dotted lines indicate the time-course of concentrations between each water renewal.

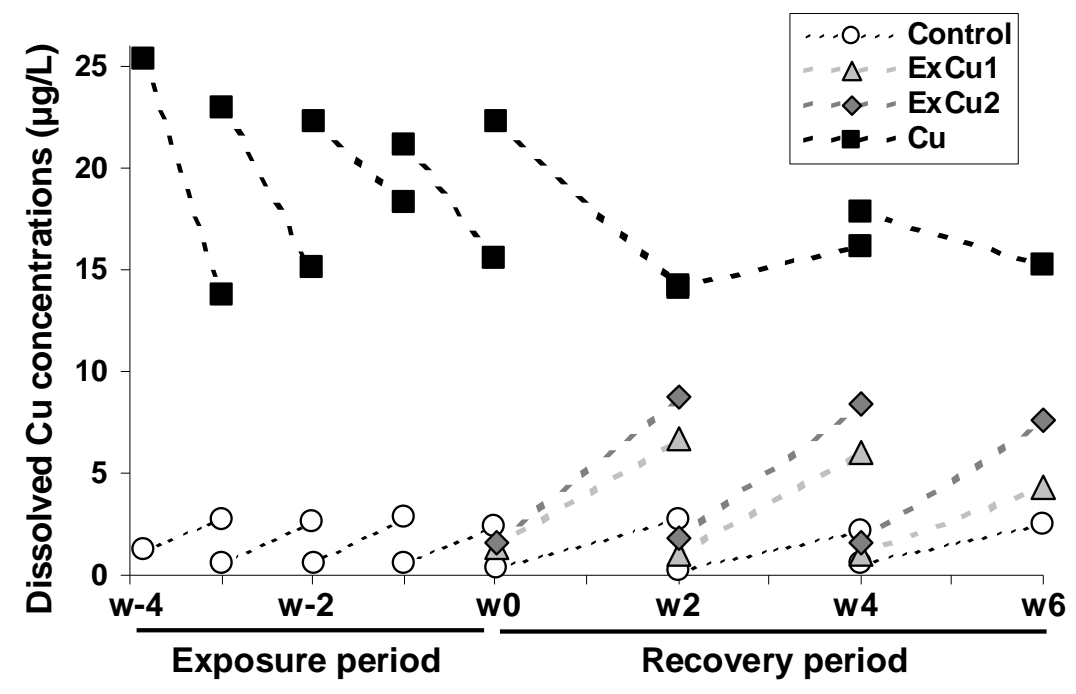


In the ExCu1 and $\mathrm{ExCu} 2$ channels, dissolved $\mathrm{Cu}$ concentrations increased from about 1.1 $( \pm 0.2)$ to $5.7( \pm 1.2) \mu \mathrm{g} \mathrm{L}-1$ and from about $1.6( \pm 0.1)$ to $8.3( \pm 0.6) \mu \mathrm{g} \mathrm{L}-1$, respectively, between each water renewal during the recovery period (Fig. 1). In parallel, total $\mathrm{Cu}$ concentrations in biofilms decreased sharply from week 0 to week 6 . This decrease, which was more pronounced in $\mathrm{ExCu} 1$ (about $233 \mu \mathrm{g} \mathrm{Cu}$ g-1 at week 6; Fig. 2) than in $\mathrm{ExCu} 2$ (about $475 \mu \mathrm{g} \mathrm{Cu}$ g-1 at week 6; Fig. 2), was mainly attributable to a decrease in extracellular $\mathrm{Cu}$ content, which fell about 20- and 5-fold in $\mathrm{ExCu} 1$ and $\mathrm{ExCu} 2$, respectively, over the course of the recovery period.

Fig 2. Mean concentrations of extracellular and intracellular $\mathrm{Cu}(\mu \mathrm{g} g-1$ dry weight of biofilm) during the 6-week recovery period in the Control (A), ExCu1 (B), $\mathrm{ExCu} 2$ (C) and $\mathrm{Cu}(\mathrm{D})$ channels.

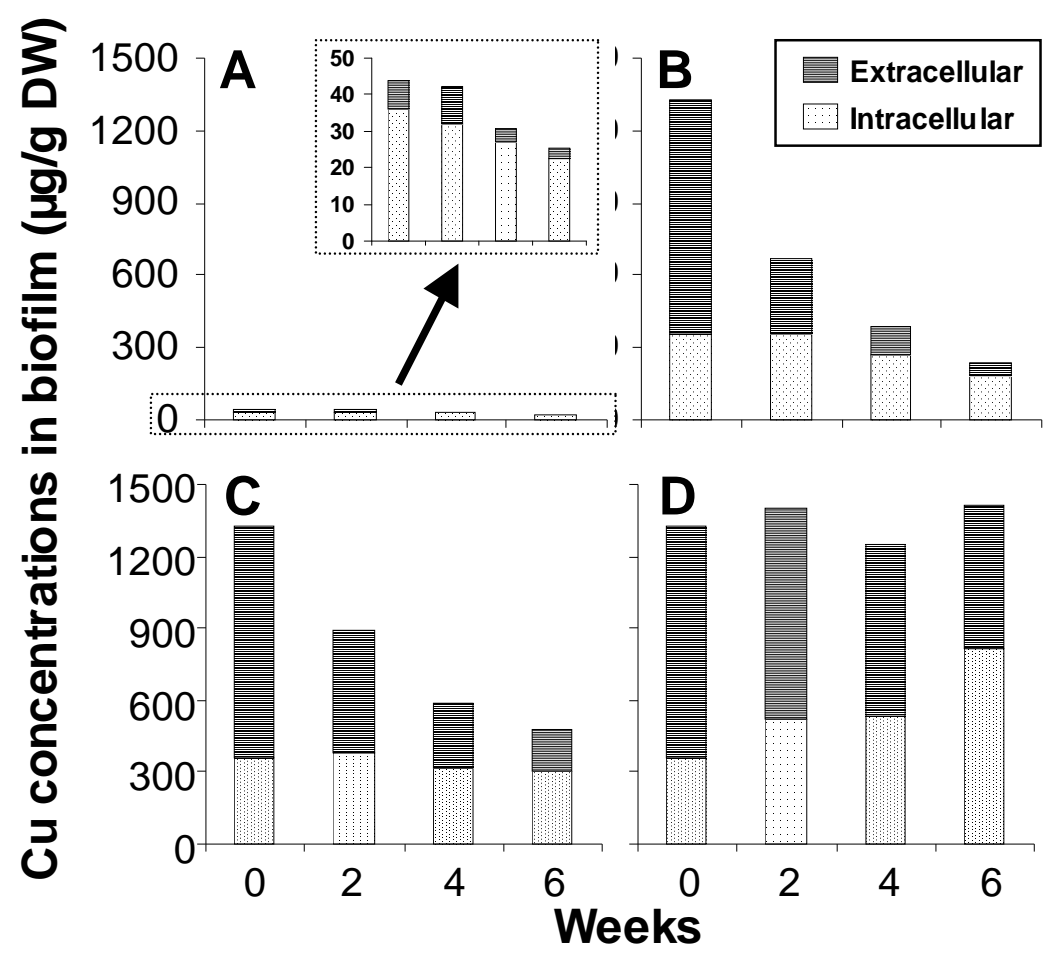

\subsection{Structural characteristics of biofilms}

\subsubsection{Total and algal biomass}

During the entire recovery period, AFDM (Fig. 3) represented more than $80 \%$ of total biofilm biomass (DW, data not shown) in all the channels. AFDM (Fig. 3) and chl a concentrations (Fig. 3) were always significantly lower in $\mathrm{Cu}$ channels than in controls. From week 2 to week 6, there were no statistical differences in AFDM concentrations between ExCu channels 
(ExCu 1 and $\mathrm{ExCu} 2$ ) and $\mathrm{Cu}$ channels (Fig. 3). Chl a concentrations (Fig. 3B) in ExCu2 were also similar to those measured in $\mathrm{Cu}$ until the end of the recovery period. In contrast, chl a concentrations increased in $\mathrm{ExCu} 1$ from week 4, reaching a similar level to that recorded in controls at the last sampling time (week 6).

Fig 3. Mean concentrations ( \pm s.d.) of biofilm ash-free dry mass (AFDM, mg cm-2, A) and chlorophyll a (chl a, $\mu \mathrm{g} \mathrm{cm}-2$, B) during the 6-week recovery period. Different letters $(a, b, c)$ indicate significant difference between channels at each sampling time (ANOVA, $\mathrm{p}<0.05, \mathrm{n}=3$ ).
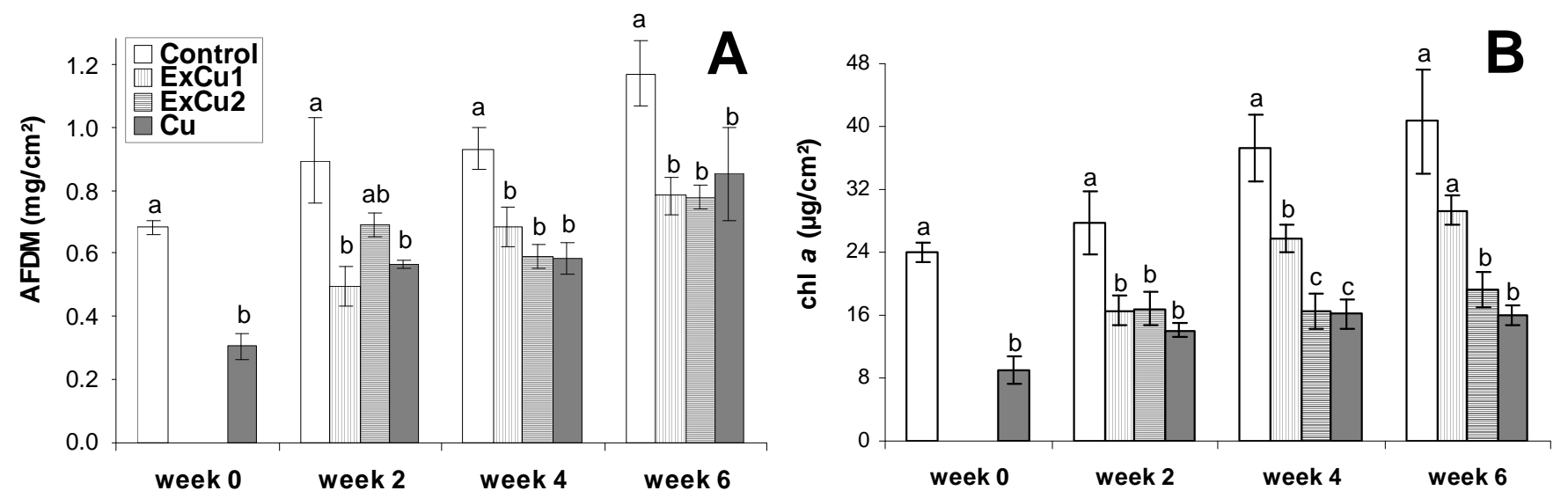

\subsubsection{Algal class composition and diatom community structure}

Algal class composition in Control and $\mathrm{Cu}$ channels remained relatively stable throughout the recovery period, with a marked difference between control communities, which were only composed of diatoms $(88 \pm 2 \%)$ and cyanobacteria $(12 \pm 2 \%)$, and $\mathrm{Cu}$ communities, which exhibited similar percentages of cyanobacteria $(12 \pm 1 \%)$ but lower percentages of diatoms $(36 \pm 5 \%)$ together with a high proportion of green algae $(52 \pm 4 \%)$.

In ExCu1 channels, there was a clear shift in algal class composition during the recovery period, and phototrophic communities showed similar profiles to those observed in controls at weeks 4 and 6. Algal community structure also evolved in $\mathrm{ExCu} 2$, with a slight decrease and increase in the proportion of green algae and diatoms, respectively. Nevertheless, changes were less pronounced than in $\mathrm{ExCu} 1$, and the percentage of green algae remained high in $\mathrm{ExCu} 2$ at the end of the recovery period $(39 \pm 3 \%)$. 
The comparison of diatom assemblages using NMDS (Fig. 4A) allowed to clearly discriminate control and $\mathrm{Cu}$ communities throughout the 6-week recovery period. ExCu1 diatom communities were very similar to those observed in controls throughout the recovery period, whereas $\mathrm{ExCu} 2$ diatom communities also changed in structure but remained clearly different to Control communities until the end of the study.

Fig 4.. Two-dimensional plot of the non-metric multidimensional analysis using diatom (microscopic taxonomic identification, A) and bacterial (PCR-ARISA analysis, B) community composition in the different channels during the 6-week recovery period (week 0 to week 6). Large symbols represent the centre of gravity of Control (o), ExCu1 ( $\square$ ), $\mathrm{ExCu} 2(\diamond)$ and $\mathrm{Cu}$ (घ) replicates, and lines show measures of dispersion $(n=3)$, at each sampling time (week $(w)$ $0-6)$.

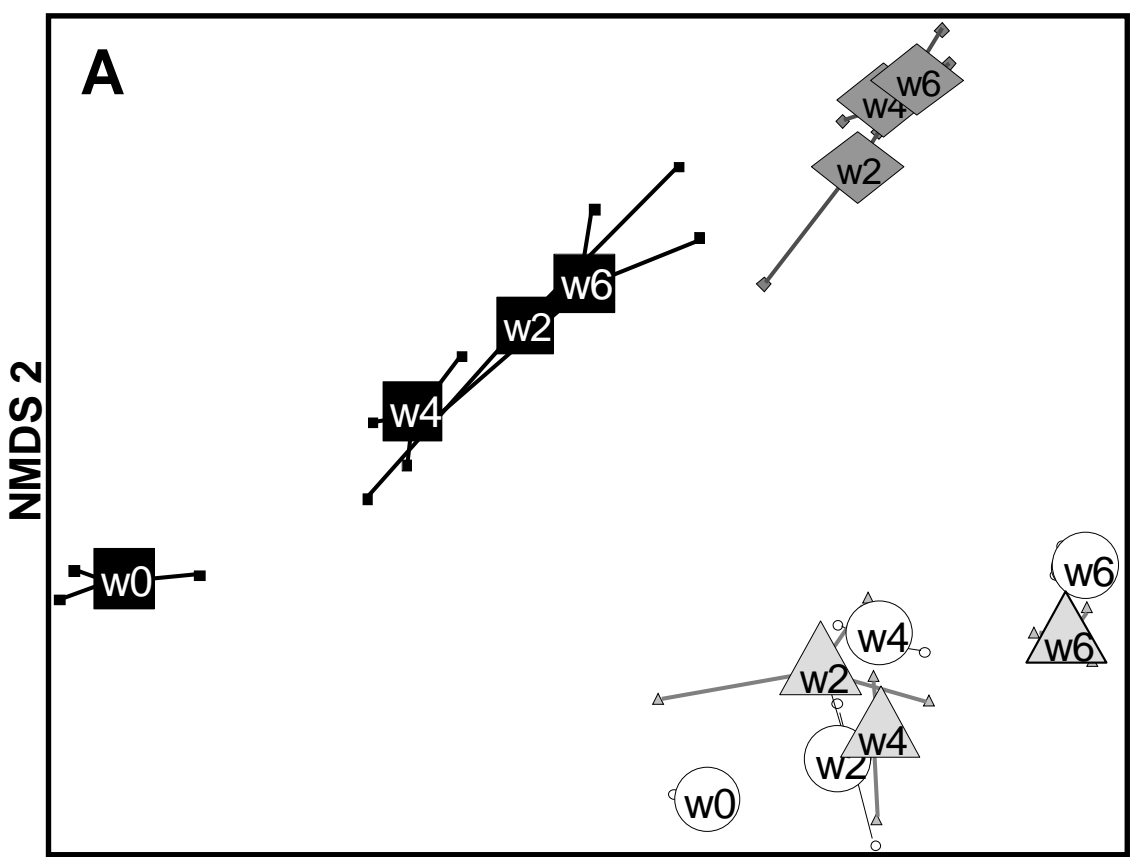

NMDS 1

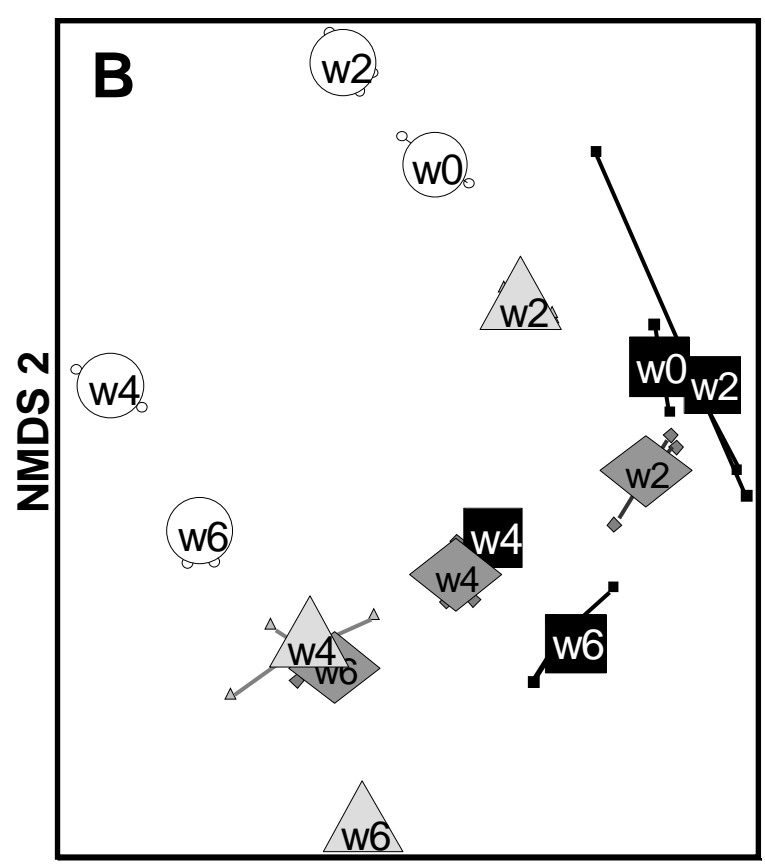

NMDS 1

\subsubsection{Bacterial community structure}

Analysis of bacterial community structure (assessed by PCR-ARISA) revealed a marked distinction between Control and $\mathrm{Cu}$ communities, as shown by NMDS (Fig. 4B). These two communities were mainly separated along the first axis. In the Control channels, the bacterial community evolved progressively over the 6-week recovery period (along the second axis), whereas the $\mathrm{Cu}$ community remained relatively stable until the end of the study. 
Bacterial community structure in $\mathrm{ExCu} 1$ and $\mathrm{ExCu} 2$ channels exhibited more pronounced temporal trends than in $\mathrm{Cu}$ channels, but was still quite distinct from controls at the end of the recovery period.

\subsection{Functional characteristics of biofilms}

\subsubsection{Photosynthetic efficiency}

Photosynthetic efficiency (Fig. 5A) measured in the Control channels remained relatively stable during the entire recovery period, without significant difference with $\mathrm{Cu}$ channels at the end of the 4-week exposure period (week 0) and during the first two weeks of the recovery period. However, photosynthetic efficiency decreased in $\mathrm{Cu}$ channels at weeks 4 and 6 and became significantly lower than the photosynthetic efficiency obtained in controls. A similar decrease was recorded in $\mathrm{ExCu} 2$ during the last two weeks, whereas Control and ExCu1 channels did not differ significantly at any point in the study.

Fig 5. Mean ( \pm s.d.) photosynthetic efficiency (PSII yield, $A)$ and $\beta$-glucosidase activity ( $\beta$ Glu, ng mg-1 AFDM h-1, B) during the 6-week recovery period. See Fig. 3 for symbol legends.
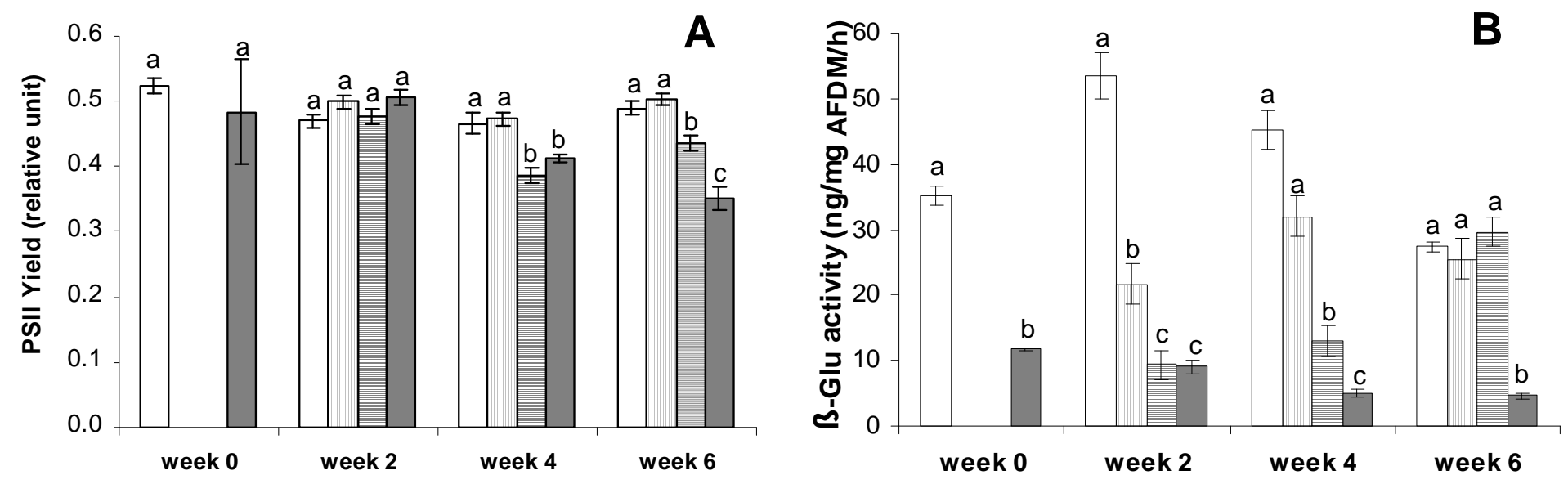

\subsubsection{Extracellular enzymatic activities}

No statistical trend was found between the different channels for LAP activity during the entire recovery period, suggesting a lack of chronic effect of copper on this heterotrophic parameter (data not shown). In contrast, $\beta$-Glu activity levels recorded in control channels 
during the recovery period were always significantly higher than those measured in $\mathrm{Cu}$ channels (Fig. 5B). There was a significant increase in $\beta$-Glu activity in ExCu channels, which exhibited no statistical difference with controls after 4 weeks (ExCu1) or 6 weeks $(\mathrm{ExCu} 2)$ of recovery.

\subsection{Biofilm tolerance to copper}

\subsubsection{Phototrophic communities}

EC50 determined from short-term toxicity tests based on chlorophyll fluorescence were higher in $\mathrm{Cu}$ channels than in controls throughout the recovery period (Fig. 6). This difference was statistically significant $(\mathrm{p}<0.05)$, except at week 2 where we found high variability between $\mathrm{Cu}$ replicates. After 6 weeks of recovery, the ExCu1 community exhibited the same tolerance level to $\mathrm{Cu}(\mathrm{EC} 50=0.09 \pm 0.03 \mathrm{mg} \mathrm{Cu} \mathrm{L}-1)$ as the Control community, whereas the $\mathrm{ExCu} 2$ community was about 4-fold more tolerant $(\mathrm{EC} 50=0.34 \pm 0.04 \mathrm{mg} \mathrm{Cu} \mathrm{L}-1)$, without significant difference with $\mathrm{Cu}$ channels.

Fig 6. Mean ( \pm s.d.) EC50 values (mg Cu L-1) determined after normalization per mg of chlorophyll a for phototrophic communities (based on chlorophyll fluorescence) during the 6week recovery period. See Fig. 3 for symbol legends.

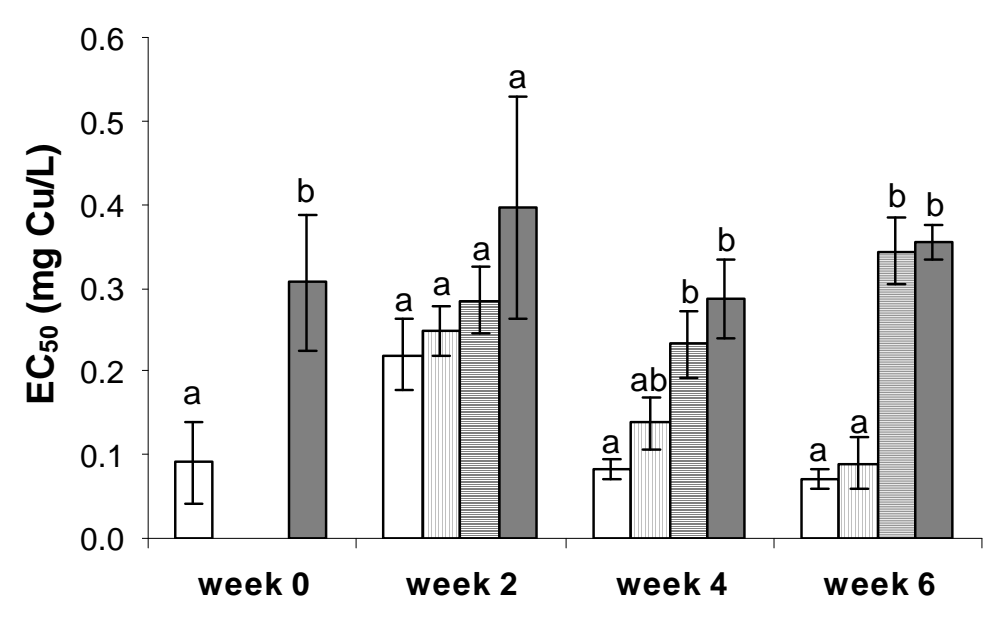

\subsubsection{Heterotrophic communities}

Short-term toxicity tests performed using $\beta$-Glu activity to assess heterotrophic biofilm community tolerance to $\mathrm{Cu}$ revealed no effect of the toxicant (in our experimental conditions) on this parameter (data not shown). Accordingly, no EC50 values were determined. 
Concentration-response curves were obtained for LAP activities, and the EC50 values obtained (normalized by $\mathrm{mg}$ of AFDM) were in the range $0.7-3.1 \mathrm{mg} \mathrm{Cu} \mathrm{L-1}$ (data not shown). The only statistical difference between Control and $\mathrm{Cu}$ communities was observed at the end of the 4-week exposure period (week 0), where $\mathrm{Cu}$ communities exhibited a 2-fold higher tolerance level $($ EC50 $=2.1 \pm 0.5 \mathrm{mg} \mathrm{Cu} \mathrm{L}-1)$ than Control communities $(\mathrm{EC} 50=0.9$ $\pm 0.2 \mathrm{mg} \mathrm{Cu} \mathrm{L}-1)$. At the other sampling dates, no clear statistical trend was found between the different channels up to the end of the recovery period.

\section{Discussion}

\subsection{Changes in $\mathrm{Cu}$ exposure conditions during the recovery period}

After a 4-week period of exposure to high concentrations of $\mathrm{Cu}(14-25 \mu \mathrm{g} \mathrm{L}-1)$, which are in the range of those previously measured in the downstream section of the Morcille River during peak contamination periods (Montuelle et al., 2010), we evaluated the ability of microbial biofilm communities to recover within 6 weeks. Two recovery dynamics scenarios were tested, i.e. biofilms only exposed to a decrease in $\mathrm{Cu}$ concentrations ( $\mathrm{ExCu} 2)$ vs. biofilms in contact with pristine communities (ExCu1). In both cases, dissolved $\mathrm{Cu}$ concentrations fluctuated between 1 and $9 \mu \mathrm{g}$ L-1 during the entire recovery period, confirming that communities were exposed to a significant decrease in $\mathrm{Cu}$ exposure, even if dissolved $\mathrm{Cu}$ concentrations in $\mathrm{ExCu}$ channels were always higher than those recorded in controls. Copper concentrations in biofilms also decreased significantly, leading to a release of $\mathrm{Cu}$ in water as shown by the increase in dissolved $\mathrm{Cu}$ concentrations between each water renewal together with biomass accrual. Boivin et al. (2006) observed similar $\mathrm{Cu}$ partitioning and exchange between water and biofilms in another recovery study. In our work, most of the release was due to a decrease in the external fraction of $\mathrm{Cu}$, which is more easily desorbable than the fraction that is sequestered intracellularly. Consequently, despite a marked decrease in extracellular $\mathrm{Cu}$ concentrations, intracellular $\mathrm{Cu}$ concentrations in the ExCu2 biofilm remained fairly constant (around $300 \mu \mathrm{g} \mathrm{g}-1$ ) until the end of the recovery period. The presence of pristine biofilms in the $\mathrm{ExCu} 1$ channel favoured the decrease in $\mathrm{Cu}$ concentrations, both in the water phase and in the previously exposed biofilm. This may be explained by the fact that part of the released $\mathrm{Cu}$ was probably accumulated in the pristine biofilms. Dissolved $\mathrm{Cu}$ concentrations were thus always lower in $\mathrm{ExCu} 1$ than in $\mathrm{ExCu} 2$, and 
$\mathrm{Cu}$ exchanges between the water phase and the biofilm were consequently stimulated in $\mathrm{ExCu} 1$. At the end of the recovery period, both total and intracellular $\mathrm{Cu}$ concentrations were about 2-fold lower in the biofilms mixed with pristine communities than in the biofilms only exposed to a decrease in dissolved $\mathrm{Cu}$ concentrations. This reveals that the presence of nonpreviously exposed biofilms influenced $\mathrm{Cu}$ dissipation kinetics during the recovery period. The difference between the two recovery contexts $(\mathrm{ExCu} 1$ vs. $\mathrm{ExCu} 2)$ was probably favoured by our experimental setup, especially by the fact that the channels were used in a recirculating mode and that water was only renewed every two weeks (thus limiting dissipation kinetics). Boivin et al. (2006) also recorded high $\mathrm{Cu}$ concentrations after 28 days of recovery in biofilms previously exposed to $\mathrm{Cu}$, despite weekly water change. Dissipation would probably have been faster in an open experimental system or in a non-polluted river section, but a translocation experiment by Dorigo et al. (2010a) showed that a 9-week recovery period was not sufficient for complete biofilm $\mathrm{Cu}$ removal.

\subsection{Recovery of phototrophic communities}

As previously shown, the 4-week $\mathrm{Cu}$ exposure strongly reduced total and algal biomass ( [Barranguet et al., 2003] , [Guasch et al., 2004] and [Serra and Guasch, 2009] ) and triggered a marked shift in the algal community structure ( [Soldo and Behra, 2000] , [Guasch et al., 2002] , [Roussel et al., 2007] , [Serra and Guasch, 2009] and [Tlili et al., 2010] ). It led to a significant increase in green algae fraction and a decrease in diatom fraction, while no change was observed in the proportion of cyanobacteria. Silica concentrations between each water renewal strongly decreased in Control channels, reflecting the high consumption by diatoms (whose biomass was higher) without toxic pressure, whereas $\mathrm{Cu}$ provoked delayed growth of this algal group.

Regardless of the presence or absence of pristine biofilms, total biomass (DW and AFDM) showed no recovery within 6 weeks. Similarly, the decrease in $\mathrm{Cu}$ exposure was not sufficient to allow the recovery of algal biomass, except when previously exposed communities were mixed with pristine communities. In the presence of pristine communities, recovery was mainly due to a marked increase of diatoms, which after 4 weeks of recovery reached proportions close to those observed in controls whereas green algae had almost completely disappeared. In the absence of pristine communities, changes in the algal community structure following the decrease in $\mathrm{Cu}$ exposure remained limited, and despite a slight increase in the 
relative abundance of diatoms, green algae remained well represented at the end of the recovery period. This study suggests that diatom immigration probably plays an important role in the recovery of phototrophic communities, as previously suggested by Morin et al. (2010). This hypothesis was strengthened by diatom taxonomic analysis, which revealed that the evolution of diatom assemblages after the decrease in $\mathrm{Cu}$ exposure clearly differed depending on whether or not pristine communities were present. Based on diatom community structure, recovery was more pronounced when species immigration processes were possible, as previously observed in various in situ translocation experiments from toxicant-polluted to pristine sites ( [Ivorra et al., 1999] , [Morin et al., 2010] and [Rotter et al., 2011] ).

In line with the PICT concept and as previously reported by Soldo and Behra (2000) and Tlili et al. (2010), the structural changes that occurred in phototrophic communities chronically exposed to $\mathrm{Cu}$ led to an increase in $\mathrm{Cu}$ tolerance. However, the level of phototrophic biofilm community tolerance to toxicants depends not only on previous chronic exposure to the toxicant but also on other environmental parameters, such as phosphate content in the water ( [Guasch et al., 2004] , [Serra et al., 2010] and [Tlili et al., 2010] ) or light exposure history ( [Guasch and Sabater, 1998] and [Laviale et al., 2010] ). In our study, the between-channel difference in $\mathrm{Cu}$ tolerance cannot be explained by variation in physicochemical characteristics (PO4 concentrations, conductivity, light, etc.), since we found no statistical differences in these parameters between the different channels. After the decrease in the exposure level, the presence of pristine biofilms greatly influenced the evolution of the tolerance capacity of phototrophic communities. At the end of the 6-week recovery period, biofilms mixed with pristine communities had lost the tolerance that had been induced during the exposure period. This recovery process was faster than the recovery described by Dorigo et al. (2010a), who observed that a 7-week recovery period after an in situ translocation was not sufficient to allow the total loss of tolerance of phototrophic communities previously exposed to $\mathrm{Cu}$, despite the proximity of non-exposed biofilms. Conversely, in our study, tolerance levels remained constant in the communities that were never mixed with pristine communities, thus revealing the lack of recovery. This difference in tolerance capacities between the two kinds of biofilms after a decrease in $\mathrm{Cu}$ exposure can possibly be explained by the immigration of more sensitive species from pristine biofilms. Nevertheless, based on our results, it cannot be excluded that the difference in both water and biofilm $\mathrm{Cu}$ concentrations between the two recovery contexts may have led to a significant difference in $\mathrm{Cu}$ exposure, thus conditioning the changes in $\mathrm{Cu}$ tolerance levels. 
Based on the measures of the photosynthetic efficiency, functional effects of chronic $\mathrm{Cu}$ exposure on phototrophic communities were only detected during the last two weeks of the study (i.e. after an 8-week exposure). Serra and Guasch (2009) also reported no effect of a 6week $\mathrm{Cu}$ chronic exposure $(30 \mu \mathrm{g}-1)$ on this parameter, revealing that structural changes are more prominent than physiological damage, as previously shown by Guasch et al. (2002). However, the effects of $\mathrm{Cu}$ on photosynthesis efficiency can vary across studies. Guasch et al. (2004) found that biofilm photosynthetic efficiency was significantly inhibited by a 6-day $\mathrm{Cu}$ exposure (15 $\mu \mathrm{g} \mathrm{L-1)}$ whatever the nutrient level, whereas Tlili et al. (2010) showed that the simultaneous addition of $\mathrm{Cu}$ and nutrients may compensate for the inhibitory effect on physiological community response. Copper may exert its toxicity by interfering with photosynthesis in the chloroplasts and ATP production (Cid et al., 1995). Photosynthesis inhibition by copper has been observed previously in various diatom species, but concentration that affects photosynthesis depends on the species assayed but diatom growth is generally more affected by copper than photosynthesis ()Cid et al., 1995). This uncoupling between division rate and photosynthesis can be due to copper inhibiting the process of cell division independently of any effect on the production of new cell material (Stauber and Florence, 1987). Here, the continuous decrease in photosynthetic efficiency observed during the four last weeks $(-30 \%)$ suggests that even if communities developed tolerance processes under chronic exposure, they were unable to maintain their photosynthetic activity throughout the study. A similar decrease in photosynthetic efficiency was also recorded during the last two weeks in biofilms exposed to a decrease in $\mathrm{Cu}$ exposure, but only when pristine communities were absent. In this case, biofilms remained exposed to sufficiently high $\mathrm{Cu}$ concentrations to inhibit photosynthetic processes. This may be explained by the lack of a significant decrease in intracellular $\mathrm{Cu}$ concentrations over the entire recovery period, thus prolonging community exposure. In $\mathrm{ExCu} 1$, one may argue that immigration processes favoured a process whereby species physiologically affected by the chronic $\mathrm{Cu}$ exposure were replaced by more active species, thus explaining the fact that no effect on photosynthetic efficiency in biofilms mixed with pristine communities during the recovery period was observed.

\subsection{Recovery of heterotrophic communities}


Genetic bacterial diversity (assessed by PCR-ARISA) greatly differed between control and exposed communities, confirming that $\mathrm{Cu}$ is a strong driver of bacterial community composition, as previously shown by using PCR-DGGE approaches ( [Massieux et al., 2004] , [Boivin et al., 2006] and [Tlili et al., 2010] ). Cu had a strong influence on bacterial community composition, which was very stable in the contaminated channels whereas controls showed a marked temporal evolution. Changes in bacterial community composition are generally strongly related to level of exposure to $\mathrm{Cu}$ ( [Massieux et al., 2004] and [Boivin et al., 2006] ) or other metals such as Cd, Zn or Ni (Fechner et al., 2011). Regardless of the presence or absence of pristine biofilms, the successional changes within the communities were more marked after the decrease in $\mathrm{Cu}$ exposure. Nevertheless, and conversely to diatom communities, bacterial community assemblages remained quite different from controls throughout the 6-week recovery period in both recovery contexts, i.e. even when pristine communities were present (i.e. when species immigration processes were possible). This result is consistent with the findings of Boivin et al. (2006), who highlighted that copperinduced changes in bacterial community composition persisted during the entire duration of our study (i.e. 4 weeks), after a decrease in $\mathrm{Cu}$ exposure level despite bacterial re-inoculation via water replenishment with natural ditch water. In a translocation experiment, Dorigo et al. (2010a) also observed a weak structural recovery of biofilm bacterial communities despite the marked decrease in pesticide exposure (including copper), the proximity of autochthonous communities and the longer duration of the recovery experiment (i.e. 9 weeks). All of these reports point to only limited implementation of immigrated bacterial species in established biofilm communities (Boivin et al., 2006), suggesting that the degree of maturity and thickness of biofilms can greatly influence structural recovery of benthic microbial communities (Dorigo et al., 2010a). However, in the present study, all the bacterial communities tend to converge after 6 weeks, suggesting that structural recovery could have been completed if the observation period would have been longer.

In our study, chronic $\mathrm{Cu}$ exposure significantly inhibited $\beta$-Glu activity. Given the high influence of algal production on bacterial glucosidase activity in biofilms (Espeland et al., 2001), one may argue that the inhibition of $\beta$-Glu activity should reflect an indirect effect of $\mathrm{Cu}$. By decreasing algal biomass, $\mathrm{Cu}$ probably indirectly limited the release of dissolved organic substances by phototrophic communities, which is an important source of high quality carbon for bacteria. This hypothesis is partially supported by the concentrations of DOC, which were notably reduced under $\mathrm{Cu}$ exposure, even if differences between channels were 
not statistically significant. This impact was detected from the end of the exposure period, suggesting that functional effects were more rapid on heterotrophic communities than on phototrophic communities. Nevertheless, we found no effect on LAP activity, revealing that the functional response to $\mathrm{Cu}$ can vary according to the type of enzymes involved. $\mathrm{Cu}$ exposure can thus affect functional diversity, as previously shown by Barranguet et al. (2003) and Boivin et al. (2006) who characterized community-level physiological profiles. Based on $\beta$-Glu activity, heterotrophic functional recovery was complete in the two recovery contexts, despite the lack of structural recovery in the bacterial communities. This confirms the existence of a high degree of functional redundancy for glucose use in microbial communities (Hill et al., 2008). Other studies have previously reported differences between structural and functional recovery following various environmental stresses ( [Griffiths et al., 2000] and [Boivin et al., 2006] ). However, the recovery in $\beta$-Glu activity was accelerated when pristine communities were present. This faster recovery in $\mathrm{ExCu}$ treatments could be explained by the greater amount of fresh and labile organic matter supplied by pristine communities and rapidly metabolized by pre-exposed communities.

While long-term exposure to $\mathrm{Cu}$ clearly inhibited $\beta$-Glu activity, no toxic effect was recorded in short-term toxicity tests using $\beta$-Glu activity as an endpoint, thus confirming that chronic effects of $\mathrm{Cu}$ on $\beta$-Glu activity were probably mainly due to indirect effects (as hypothesized above). This is quite surprising given that several authors have successfully completed PICT approaches by measuring $\beta$-Glu activity following short-term exposure to increasing $\mathrm{Cu}$ concentrations ( [Fechner et al., 2010] and [Tlili et al., 2010] ). We are unable to explain the lack of effect in our toxicity tests, since the range of the $\mathrm{Cu}$ concentrations (final concentrations reaching $127 \mathrm{mg} \mathrm{L}-1)$ and the duration of exposure ( $4 \mathrm{~h}$ before incubation with the substrate) were quite similar to those previously described ( [Fechner et al., 2010] and [Tlili et al., 2010] ). In contrast, concentration-response curves were obtained for LAP activities whereas no effect was recorded on this parameter during the chronic exposure. After the 4-week exposure period, the chronically exposed community was about 2-fold more tolerant to $\mathrm{Cu}$ than the controls. Based on LAP activity measurement, Tlili et al. (2010) also observed an increase in $\mathrm{Cu}$ tolerance following a 3-week chronic $\mathrm{Cu}$ exposure $(25 \mu \mathrm{g} \mathrm{L}-1)$. However, in our study, the increase in tolerance was only transient, and there were no differences between exposed and non-exposed communities over the last 6 weeks of study. Thus, our results did not allow us to assess possible recovery of the tolerance capacities of heterotrophic microbial communities. 


\section{Conclusions}

This study revealed that the structural and functional recovery of biofilm communities was greatly influenced by the presence or absence of pristine biofilms. However, microbial community responses following the decrease in $\mathrm{Cu}$ exposure differed between phototrophic and heterotrophic communities. When pre-exposed biofilms were connected to pristine biofilms, phototrophic communities recovered within 6 weeks, both in terms of biomass, structure and photosynthetic activity. Recovery processes were also detected using the PICT approach, since the tolerance induced during the chronic exposure to $\mathrm{Cu}$ totally disappeared during the recovery period. In contrast, all of the $\mathrm{Cu}$-induced changes recorded in phototrophic communities remained present throughout the recovery period in the absence of pristine communities. Our results seem to confirm that immigration processes should play a major role in phototrophic biofilm community recovery.

The presence of pristine communities had less influence on the trajectory of recovery in heterotrophic communities suggesting a limited role of immigration processes. Regardless of the presence or absence of pristine biofilms, the decrease in $\mathrm{Cu}$ exposure did not totally abolish $\mathrm{Cu}$-induced changes in bacterial community structure within 6 weeks even if community trajectories suggested partial recovery. In contrast, functional recovery (based on $\beta$-Glu activity) was completed in both recovery contexts. This indicates that genetically different bacterial communities can sustain similar ecological functions, especially when considering generalist ones, such as glycosidase activities. It is thus possible that recovery dynamics of more specific functions are more dependent on community structure and diversity.

From an ecological perspective, this study suggests that the recovery of stream microbial biofilm communities following an improvement in water chemical quality would be facilitated in settings where microorganisms can immigrate from previously noncontaminated areas. It would thus be crucial to protect upstream sections from most of the chemical pollution in order to allow the development of pristine biofilms that could colonize downstream sections after chemical restoration.

\section{Acknowledgments}


We thank ATT for editing the English-language version of the manuscript. We also thank Bernard Motte and Christophe Rosy for technical support, Arnaud Foulquier for statistical analysis, and the Irstea's Water Chemistry Laboratory (LAMA) for physico-chemical data, and especially Hélène Sanejouand for nutrient analysis and Josiane Gahou and Eloïse Vray for copper analysis.

This project was supported by funding from the French National Office for the Aquatic Environment (ONEMA-ONEMA-CEMAGREF agreement, action 26, "Remédiation de l'effet de pesticides").

\section{References}

Barranguet, C., van den Ende, F.P., Rutgers, M., Breure, A.M., Greijdanus, M., Sinke, J.J., Admiraal, W., 2003. Copper-induced modifications of the trophic relations in riverine algal-bacterial biofilms. Environmental Toxicology and Chemistry 22, 1340-1349.

Battin, T.J., Kaplan, L.A., Newbold, J.D., Hansen, C.M.E., 2003. Contributions of microbial biofilms to ecosystem processes in stream mesocosms. Nature 426, 439-441.

Blanck, H., Wängberg, S.A., Molander, S., 1988. Pollution-induced community tolerance - a new ecotoxicological tool. In: Cairns, J., Pratt, J.R. (Eds), Functional testing of aquatic biota for estimating hazards of chemicals, Philadelphia, ASTM STP 988, 219-230.

Boivin, M.E.Y., Massieux, B., Breure, A.M., Greve, G.D., Rutgers, M., Admiraal, W., 2006. Functional recovery of biofilm bacterial communities after copper exposure. Environmental Pollution 140, 239-246.

Bossuyt, B.T.A., Janssen, C.R., 2004. Long-term acclimation of Pseudokirchneriella subcapitata (Korshikov) Hindak to different copper concentrations: changes in tolerance and physiology. Aquatic Toxicology 68, 61-74.

Cid, A., Herrero, C., Torres, E., Abalde, J., 1995. Copper toxicity on the marine microalga Phaeodactylum tricornutum: effects on photosynthesis and related parameters. Aquatic Toxicology 31, 165-174.

Depledge, M.H., 1999. Recovery of ecosystems and their components following exposure to pollution. Journal of Aquatic Stress and Recovery 6, 199-206.

Dorigo, U., Bérard, A., Rimet, F., Bouchez, A., Montuelle, B., 2010a. In situ assessment of periphyton recovery in a river contaminated by pesticides. Aquatic Toxicology 98, 396406.

Dorigo, U., Bérard, A., Bouchez, A., Rimet, F., Montuelle, B., 2010b. Transplantation of microbenthic algal assemblages to assess structural and functional recovery after diuron exposure. Archives of Environmental Contamination and Toxicology 59, 555-563.

Espeland, E.M., Francoeur, S.N., Wetzel, R.G., 2001. Influence of algal photosynthesis on biofilm bacterial production and associated glucosidase and xylosidase activities. Microbial Ecology 42, 524-530.

Fechner, L.C., Gourlay-Francé, C., Uher, E., Tusseau-Vuillemin, M.H., 2010. Adapting an enzymatic toxicity test to allow comparative evaluation of natural freshwater biofilms' tolerance to metals. Ecotoxicology 19, 1302-1311. 
Fechner, L.C., Gourlay-Francé, C., Tusseau-Vuillemin, M.H., 2011. Low exposure levels of urban metals induce heterotrophic community tolerance: a microcosm validation. Ecotoxicology 20, 793-802.

Griffiths, B.S., Ritz, K., Bardgett, R.D., Cook, R., Christensen, S., Ekelund, F., Sørensen, S.J., Baath, E., Bloem, J., De Ruiter, P.C., Dolfing, J., Nicolardot; B., 2000. Ecosystem response of pasture soil communities to fumigation-induced microbial diversity reductions: an examination of the biodiversity-ecosystem function relationship. Oikos 90, 279-294.

Guasch, H., Sabater, S., 1998. Light history influences the sensitivity to atrazine in periphytic algae. Journal of Phycology 34, 233-241.

Guasch, H., Paulsson, M., Sabater, S., 2002. Effect of copper on algal communities from oligotrophic calcareous streams. Journal of Phycology 38, 241-248.

Guasch, H., Navarro, E., Serra, A., Sabater, S., 2004. Phosphate limitation influences the sensitivity to copper in periphytic algae. Freshwater Biology 49, 463-473.

Hill, P.W., Farrar, J.F., Jones, D.L., 2008. Decoupling of microbial glucose uptake and mineralization in soil. Soil Biology and Biochemistry 40, 616-624.

Ihaka, R., Gentleman, R., 1996. R: A language for data analysis and graphics. ournal of Computational and Graphical Statistics 5, 299-314.

Ivorra, N., Hettelaar, J., Tubbing, G.M.J., Kraak, M.H.S., Sabater, S., Admiraal, W., 1999. Translocation of microbenthic algal assemblages used for in situ analysis of metal pollution in rivers. Archives of Environmental Contamination and Toxicology 37, 1928.

Krammer, K. and Lange-Bertalot, H. 1986-1991. Bacillariophyceae 1. Teil: Naviculaceae, 2. Teil: Bacillariaceae, Epithemiaceae, Surirellaceae, 3. Teil: Centrales, Fragilariaceae, Eunotiaceae, 4. Teil: Achnanthaceae. Kritische Ergänzungen zu Navicula (Lineolatae) und Gomphonema. G. Fischer Verlag., Stuttgart.

Laviale, M., Prygiel, J., Créach, A., 2010. Light modulated toxicity of isoproturon toward natural stream periphyton photosynthesis: A comparison between constant and dynamic light conditions. Aquatic Toxicology 97, 334-342.

Massieux, B., Boivin, M.E.Y., van den Ende, F.P., Langenskiöld, J., Marvan, P., Barranguet, C., Admiraal, W., Laanbroek, H.J., Zwart, G., 2004. Analysis of structural and physiological profiles to assess the effects of $\mathrm{Cu}$ on biofilm microbial communities. Applied and Environmental Microbiology 70, 4512-4521.

Montuelle, B., Dorigo, U., Bérard, A., Volat, B., Bouchez, A., Tlili, A., Gouy, V., Pesce, S., 2010. The periphyton as a multimetric bioindicator for assessing the impact of land use on rivers: an overview of the Ardières-Morcille experimental watershed. Hydrobiologia 657, 123-141.

Morin, S., Pesce, S., Tlili, A., Coste, M., Montuelle, B., 2010. Recovery potential of periphytic communities in a river impacted by a vineyard watershed. Ecological Indicators 10, 419-426.

Ranjard, L., Poly, F.., Lata, J.C., Mougel, C., Thioulouse, J., Nazaret, S., 2001. Characterization of bacterial and fungal soil communities by automated ribosomal intergenic spacer analysis fingerprints: biological and methodological variability. Applied and Environmental Microbiology 67, 4479-4487.

Romani, A. M., Guasch, H., Munoz, I., Ruana, J., Vilalta, E., Schwartz, T., Emtiazi, F., Sabater, S., 2004. Biofilm structure and function and possible implications for riverine DOC dynamics. Microbial Ecology 47, 316-328.

Rotter, S., Sans-Piché, F., Streck, G., Altenburger, R., Schmitt-Jansen, M., 2011. Active biomonitoring of contamination in aquatic systems - An in situ translocation experiment applying the PICT concept. Aquatic Toxicology 101, 228-236. 
Roussel, H., Ten-Hage, L., Joachim, S., Le Cohu, R., Gauthier, L., Bonzom, J.M., 2007. A long-term copper exposure on freshwater ecosystem using lotic mesocosms: Primary producer community responses. Aquatic Toxicology 81, 168-182.

Sabater, S., Guasch, H., Ricart, M., Romani, A., Vidal, G., Klünder, C., Schmitt-Jansen, M., 2007. Monitoring the effect of chemicals on biological communities. The biofilm as an interface. Analytical and Bioanalytical Chemistry 387, 1425-1434.

Schmitt-Jansen, M., Altenburger, R., 2008. Community-level microalgal toxicity assessment by multiwavelength-excitation PAM fluorometry. Aquat. Toxicol. 86, 49-58.

Serra, A., Guasch, H., 2009. Effects of chronic copper exposure on fluvial systems: Linking structural and physiological changes on fluvial biofilms with the in-stream copper retention. Science of the Total Environment 407, 5274-5282.

Serra, A., Guasch, H., Admiraal, W., Van der Geest, H.G., Van Beusekom, S.A.M., 2010. Influence of phosphorus on copper sensitivity of fluvial periphyton: the role of chemical, physiological and community-related factors. Ecotoxicology 19, 770-780.

Soldo, D., Behra, R., 2000. Long-term effects of copper on the structure of freshwater periphyton communities and their tolerance to copper, zinc, nickel and silver. Aquatic Toxicology 47, 181-189.

Stauber, J.L., Florence, T.M., 1987. Mechanism of toxicity of ionic copper and copper complexes to algae. Marine Biology 94, 51 I-519.

Stevenson, R.J., Peterson, C.G., 1989. Variation in benthic diatom (Bacillariophyceae) immigration with habitat characteristics and cell morphology. Journal of Phycology 25, 120-129.

Stevenson, R.J., Peterson, C.G., 1991. Emigration and immigration can be important determinants of benthic diatom assemblages in streams. Freshwater Biology 26, 279294.

Tlili, A., Bérard, A., Roulier, J.L., Volat, B., Montuelle, B., 2010. $\mathrm{PO}_{4}{ }^{3-}$ dependence of the tolerance of autotrophic and heterotrophic biofilm communities to copper and diuron. Aquatic Toxicology 98, 165-177.

Tlili, A., Corcoll, N., Bonet, B., Morin, S., Montuelle, B., Bérard, A., Guasch, H., 2011. In situ spatio-temporal changes in pollution-induced community tolerance to zinc in autotrophic and heterotrophic biofilm communities. Ecotoxicology DOI 10.1007/s10646-011-0721-2

Tolcach, E.R., Gómez, N., 2002. Effect of translocation of microbenthic communities in a polluted lowland stream. Verhandlungen des Internationalen Verein Limnologie 28, 254-258. 